\title{
PEMBERIAN KOMBINASI VITAMIN B1, B6 DAN B12 SEBAGAI FAKTOR DETERMINAN PENURUNAN NILAI TOTAL GEJALA PADA PASIEN NEUROPATI PERIFER DIABETIK
}

\author{
Ratna Sari Kusuma Dewi, Rizaldy Taslim Pinzon*), Sapto Priatmo \\ Fakultas Kedokteran Universitas Kristen Duta Wacana, Jl. Dr. Wahidin Sudirohusodo 5-25 \\ Yogyakarta 55224, Indonesia
}

Received August 8, 2016; Accepted September 1, 2016

\begin{abstract}
Diabetic neuropathy is defined as symptoms of peripheral nerve dysfunction in people with diabetes after the exclusion of other causes. According to the earlier studies symptoms of neuropathy such as pain, burning, paresthesia/tingling and numbness can be reduced with neurotropic supplementation. The aim of the research is to determine vitamin $B_{1}, B_{6}$ and $B_{12}$ as a determinant factor in the reduce total symptom score in patient with diabetic peripheral neuropathy. This research used case series studies and choose 43 sample with consecutive sampling method. We observed symptoms of diabetic peripheral neuropathy (pain, burning, tingling and numbness) measured as total symptoms score, among the patients treated with vitamin $B_{1}(100 \mathrm{mg}), B_{6}(100 \mathrm{mg})$ and $B_{12}$ (5000mcg) for a month. Measurement of total symptoms score performed at first meeting, the second week later (day-14) and the fourth week later (day30). The data were analyzed using univariate and bivariate statistics. The patients $(n=43)$ consisted of 20 male (46.5\%) and 23 female (53.5\%). The symptoms of diabetic peripheral neuropathy (pain, burning, tingling and numbness) that measured by total symptoms score compared with first visit (4.70 \pm 1.83$)$, second visit $(2.99 \pm 1.61)$ and third $(2: 37 \pm 1.62)$. Bivariate analysis, showed a correlation between a reduction in total symptoms score after giving therapy of vitamin $B_{1}(100 m g), B_{6}(100 m g)$ and $B_{12}$ (5000mcg) with $p=0.00$. Vitamin $B_{1}, B_{6}$ and $B_{12}$ proved to be a determinant factor to reduce total symptoms score (pain, burning, tingling, and numbness) in patients with diabetic peripheral neuropathy.
\end{abstract}

Key words: Diabetic peripheral neuropathy, vitamin $B_{1}, B_{6}$ and $B_{12}$, total symptoms score

\section{PENDAHULUAN}

Penderita diabetes mellitus di Indonesia mengalami peningkatan dari tahun ke tahun. Berdasarkan sumber dari International Diabetes Federation (IDF) Diabetes atlas tahun 2013, Indonesia menduduki peringkat terbanyak ke-5 di dunia dengan jumlah penderita mencapai 8.554.155 orang. Neuropati Perifer Diabetik (NPD) merupakan salah satu komplikasi kronis paling banyak ditemukan pada diabetes mellitus. Neuropati perifer diabetik memiliki variasi manifestasi, antara lain dengan keluhan nyeri hebat maupun tanpa keluhan. Gejala dari neuropati perifer diabetik yang sering dirasakan pasien antara lain nyeri, rasa terbakar, parasthesia (kesemutan dan rasa terutusuk), mati rasa, dan lain-lain (Sudoyo, 2009).
Penurunan gejala neuropati dengan farmakoterapi yang dapat digunakan antara lain dengan antikonvulsan, antidepresan dan neurotropik yang termasuk didalamnya adalah vitamin $\mathrm{B}_{1}, \mathrm{~B}_{6}$, dan $\mathrm{B}_{12}$. Vitamin neurotropik berfungsi menormalkan fungsi saraf dengan memperbaiki gangguaan metabolisme saraf melalui pemberian asupan yang dibutuhkan (Perdossi, 2012). Pemberian vitamin $B_{1} \quad(100 \mathrm{mg}), \quad B_{6}$ (100mg), dan $B_{12}(200 \mathrm{mcg})$ terbukti efisien dalam penurunan gejala neuropati pada sekitar $87,4 \%$ pasien dari 310 pasien neuropati perifer diabetic (Rizvi, 2013). Kurangnya data yang tersedia mengenai vitamin $\mathrm{B}_{1}, \mathrm{~B}_{6}$, dan $\mathrm{B}_{12}$ sebagai faktor determinan penurunan gejala neuropati perifer diabetik (nyeri, terbakar, kesemutan dan mati rasa), serta semakin meningkatnya angka kejadian neuropati perifer diabetes, sehingga peneliti ingin 
mengetahui lebih lanjut tentang pengaruh vitamin $\mathrm{B}_{1}, \mathrm{~B}_{6}$, dan $\mathrm{B}_{12}$ terhadap gejala neuropati perifer diabetes (nyeri, rasa terbakar, kesemutan dan mati rasa).

Penelitian ini menggunakan disain case series. Peneliti akan melakukan pengamatan pada pasien neuropati perifer diabetik yang didiagnosis dengan metode skrining neuropati perifer diabetik yaitu Michigan Neuropathy Screening Instrument (MNSI) atau Toronto clinical neuropathy Score (TCNS). Pasien yang memiliki score yang sesuai dengan kriteria diagnosis dan kriteria penelitian akan dijadikan sebagai subjek penelitian. Pemilihan disain case series dikarenakan penelitian ini bersifat pengamatan dalam kurun waktu tertentu yang dilakukan pada pasien neuropati perifer diabetik yang diberikan terapi untuk memperbaiki gejala yang diderita. Hal ini merupakan keterbatasan peneliti tidak dapat melakukan intervensi terapi langsung kepada pasien.

\section{METODE PENELITIAN}

Penelitian ini dilaksanakan di poliklinik rumah sakit dengan menggunakan disain case series. Peneliti melakukan pengamatan pada subjek yang terskrining dan terdiagnosa neuropati perifer diabetik serta dilakukan pengukuran derajat neuropati perifer diabetik yang kemudian diberi vitamin $\mathrm{B}_{1}, \mathrm{~B}_{6}, \mathrm{~B}_{12}$ selama 1 bulan oleh Dokter. Skrining dan pengukuran derajat neuropati pada subjek dilakukan pada hari ke-0, setelah masuk dalam kriteria penelitian subjek diberikan terapi vitamin $\mathrm{B}_{1}(100 \mathrm{mg}), \mathrm{B}_{6}(100 \mathrm{mg}), \mathrm{B}_{12}(5000 \mathrm{mcg})$ oleh Dokter. Penelitian dilakukan selama 30 hari pada setiap pasien. Kunjungan atau follow up pasien dilakukan pada hari ke-14 atau sekitar 2 minggu pemakain terapi dan pada hari ke-30 atau 1 bulan. Setiap kali kunjungan yang dilakukan, pasien akan diperiksa kembali derajat neuropatinya.

Subjek yang mengalami gejala neuropati perifer diabetik akan didiagnosa dengan metode Michigan Neuropathy Screening Instrument (MNSI) atau Toronto clinical neuropathy Score (TCNS) yang merupakan salah satu skrining yang dapat dilakukan pada penderita diabetes mellitus yang diduga mengalami komplikasi khususnya saraf tepi (Geffari, 2012) (Brill, 2008). Pengukuran derajat neuropati akan dilakukan pada setiap kunjungan dengan metode Total Symptom Score (TSS) dengan menilai gejala antara lain intensitas nyeri, sensasi terbakar, kesemutan, dan mati rasa. Data total symptoms score kemudian dibandingkan dengan pemberian terapi vitamin $\mathrm{B}_{1}(100 \mathrm{mg}), \mathrm{B}_{6}$ $(100 \mathrm{mg}), B_{12}(5000 \mathrm{mcg})$ setiap kunjungan yang kemudian dilihat penurunan gejala neuropati yang bermakna pada setiap kunjungan setelah pemakaian terapi vitamin $\mathrm{B}_{1}, \mathrm{~B}_{6}$ dan $\mathrm{B}_{12}$. Pengukuran kemudian diolah dengan analisis deskriptif melalui analisis univariat dan bivariat.

\section{HASIL DAN PEMBAHASAN}

Peneliti melakukan pengamatan pada pasien yang diberikan kombinasi vitamin B forte satu kali sehari selama 1 bulan. Hasil yang terpapar pada tabel I, subyek penelitian terdiri atas laki-laki sebanyak $46.5 \%$ dan perempuan $53.5 \%$ dengan rerata usia $56.35 \pm 5.82$. Terapi diabetes terbanyak pada penelitian ini adalah penggunaan hiperglikemik oral yang digunakan oleh $42(97,7 \%)$ pasien, sedangkan terapi insulin hanya digunakan pada $4(9,3 \%)$ pasien. Pada tabel II, rata-rata nilai total symptoms score pada pasien dibandingan dengan pemberian terapi vitamin $\mathrm{B}_{1}, \mathrm{~B}_{6}$ dan $\mathrm{B}_{12}$ kunjungan 1, kunjungan 2 dan kunjungan 3 terlihat menurun pada setiap kunjungan.

Pada uji statistik dilakukan dengan metode Wilcoxon untuk mendapatkan nilai kebermaknaan perbandingan antara kelompok. Tabel III pada variabel usia didapatkan hasil rerata usia pada penelitian ini adalah $56,35 \pm 5,82$ yang kemudian dibandingan dengan nilai total symptoms score muncul nilai kebermaknaan pada kunjungan hari kedua, hasil uji statistik dilanjutkan dengan uji korelasi pada tabel IV, antara perbandingan usia dengan nilai delta total symptoms score tiap kunjungan yang didapatkan ternyata usia tidak berpengaruh terhadap penurunan gejala. Usia dan durasi DM memiliki nilai rerata yang konstan pada setiap kunjungan sehingga, hasil yang sama juga ditemukan pada durasi DM, dimana tidak ditemukan adanya hubungan durasi DM dengan perbaikan gejala pada pasien yang diukur dengan total symptoms score.

Pasien yang tidak merokok memiliki nilai total symptoms score lebih tinggi dibandingan pasien 
yang merokok sebelum pasien menerima terapi neuropati dan pasien dengan dislipidemia pada pertemuan 2, memiliki nilai total symptoms score lebih rendah dibandingkan dengan pasien yang tidak memiliki dislipidemia. Pada tabel V didapatkan bahwa penurunan gejala (nyeri, rasa terbakar, kesemutan dan mati rasa) yang diukur dengan menggunakan Total Symptoms Score penurunan yang bermakna pada setiap kunjungan, setelah diberikan kombinasi vitamin $\mathrm{B}$ forte $\left(\mathrm{B}_{1}\right.$ : $100 \mathrm{mg}$; $\mathrm{B}_{6}: 100 \mathrm{mg} ; \mathrm{B}_{12}: 5000 \mathrm{mcg}$ ).

Hipotesis pada penelitian ini adalah pemberian kombinasi vitamin $\mathrm{B}_{1}, \mathrm{~B}_{6}$ dan $\mathrm{B}_{12}$ sebagai faktor determinan penurunan nilai total gejala atau total symptoms score pada pasien neuropati diabetes. Penggunaan total symptoms score dipilih karena peneliti dapat mengamati langsung 4 gejala sekaligus pada pasien neuropati diabetes.

Tabel I. Karakteristik Data Pasien Neuropati Perifer Diabetik

\begin{tabular}{|c|c|c|}
\hline Variabel & $\mathrm{n}=43$ & $\%$ \\
\hline Usia (tahun), mean \pm SD & $56,35 \pm 5,82$ & \\
\hline Durasi DM(tahun), mean \pm SD & $4,47 \pm 4,96$ & \\
\hline \multicolumn{3}{|l|}{ Jenis kelamin } \\
\hline Perempuan & 23 & 53,5 \\
\hline Laki-laki & 20 & 46,5 \\
\hline \multicolumn{3}{|l|}{ Terapi OHO } \\
\hline Tidak & 1 & 2,3 \\
\hline Ya & 42 & 97,7 \\
\hline \multicolumn{3}{|l|}{ Terapi Insulin } \\
\hline Tidak & 39 & 90,7 \\
\hline Ya & 4 & 9,3 \\
\hline \multicolumn{3}{|l|}{ Merokok } \\
\hline Tidak & 40 & 93 \\
\hline $\mathrm{Ya}$ & 3 & 7 \\
\hline \multicolumn{3}{|l|}{ Hipertensi } \\
\hline Tidak & 26 & 60,5 \\
\hline $\mathrm{Ya}$ & 17 & 39,5 \\
\hline \multicolumn{3}{|l|}{ Dislipidemia } \\
\hline Tidak & 32 & 74,4 \\
\hline Ya & 11 & 25,6 \\
\hline \multicolumn{3}{|l|}{ Ulkus diabetikum } \\
\hline Tidak & 42 & 97,7 \\
\hline Ya & 1 & 2,3 \\
\hline \multicolumn{3}{|l|}{ Morisky } \\
\hline Tingkat kepatuhan sedang (skor $6-<8$ ) & 1 & 2,3 \\
\hline Tingkat kepatuhan tinggi (skor 8) & 42 & 97,7 \\
\hline
\end{tabular}

Tabel II. Nilai Total Symptoms Score tiap kunjungan

\begin{tabular}{cccc}
\hline \multirow{2}{*}{ Variabel } & Kunjungan 1 & Kunjungan 2 & Kunjungan 3 \\
\cline { 2 - 4 } Total Symptoms Score & \multicolumn{3}{c}{ Mean \pm SD } \\
\cline { 2 - 4 } & $4,70 \pm 1,83$ & $2,99 \pm 1,61$ & $2,37 \pm 1,62$ \\
\hline
\end{tabular}


Tabel III. Faktor-faktor yang berpengaruh terhadap Total Symptom Score

\begin{tabular}{|c|c|c|c|c|c|c|}
\hline \multirow[t]{2}{*}{ Variabel } & \multicolumn{6}{|c|}{ Pengukuran dengan Total Symptom Score } \\
\hline & $\begin{array}{l}\text { Hari ke-0 } \\
\text { Mean } \pm \text { SD }\end{array}$ & $\begin{array}{c}p- \\
\text { value }\end{array}$ & $\begin{array}{c}\text { Hari ke- } \\
14 \\
\text { Mean } \pm \text { SD }\end{array}$ & $\begin{array}{c}p- \\
\text { value }\end{array}$ & $\begin{array}{l}\text { Hari ke-30 } \\
\text { Mean } \pm \text { SD }\end{array}$ & $\begin{array}{c}p- \\
\text { value }\end{array}$ \\
\hline Usia & $56,35 \pm 5,82$ & 0,12 & $\begin{array}{c}56,35 \pm 5,8 \\
2\end{array}$ & $0,04 *$ & $\begin{array}{c}56,35 \pm 5,8 \\
2\end{array}$ & 0,05 \\
\hline Durasi DM & $4,47 \pm 4,96$ & 0,97 & $4,47 \pm 4,96$ & 0,99 & $4,47 \pm 4,96$ & 0,53 \\
\hline \multicolumn{7}{|l|}{ Jenis Kelamin } \\
\hline - $\quad$ Perempuan & $5,18 \pm 1,86$ & 0,09 & $3,08 \pm 1,81$ & 0,76 & $2,64 \pm 1,85$ & 0,35 \\
\hline - $\quad$ Laki-laki & $4,16 \pm 1,68$ & & $2,89 \pm 1,39$ & & $2,06 \pm 1,28$ & \\
\hline \multicolumn{7}{|l|}{ Terapi OHO } \\
\hline - $\quad$ Tidak & $2,33 \pm 0$ & 0,18 & $2,00 \pm 0$ & 0,55 & $2,00 \pm 0$ & 0,97 \\
\hline$-\quad \mathrm{Ya}$ & $4,76 \pm 1,81$ & & $3,02 \pm 1,62$ & & $2,38 \pm 1,64$ & \\
\hline \multicolumn{7}{|l|}{ Terapi Insulin } \\
\hline - $\quad$ Tidak & $4,71 \pm 1,83$ & 0,95 & $3,06 \pm 1,58$ & 0,45 & $2,39 \pm 1,60$ & 0,92 \\
\hline$-\quad \mathrm{Ya}$ & $4,65 \pm 2,08$ & & $2,33 \pm 2,05$ & & $2,24 \pm 2,05$ & \\
\hline \multicolumn{7}{|l|}{ Merokok } \\
\hline - $\quad$ Tidak & $4,88 \pm 1,75$ & $0,02 *$ & $3,12 \pm 1,56$ & 0,08 & $2,45 \pm 1,61$ & 0,25 \\
\hline$-\quad \mathrm{Ya}$ & $2,33 \pm 1,19$ & & $1,33 \pm 1,52$ & & $1,33 \pm 1,52$ & \\
\hline \multicolumn{7}{|l|}{ Hipertensi } \\
\hline - $\quad$ Tidak & $4,86 \pm 1,99$ & 0,49 & $2,99 \pm 1,64$ & 0,98 & $2,43 \pm 1,64$ & 0,73 \\
\hline$-\quad \mathrm{Ya}$ & $4,46 \pm 1,57$ & & $2,99 \pm 1,62$ & & $2,29 \pm 1,62$ & \\
\hline \multicolumn{7}{|l|}{ Dislipidemia } \\
\hline - Tidak & $4,78 \pm 1,85$ & 0,69 & $3,27 \pm 1,58$ & $0,04 *$ & $2,56 \pm 1,49$ & 0,06 \\
\hline$-\quad \mathrm{Ya}$ & $4,47 \pm 1,82$ & & $2,18 \pm 1,47$ & & $1,84 \pm 1,93$ & \\
\hline \multicolumn{7}{|l|}{ Morisky } \\
\hline - $\quad$ Tingkat kepatuhan sedang (skor 6-<8) & $4,00 \pm 0$ & 0,74 & $1,00 \pm 0$ & 0,196 & $1,00 \pm 0$ & 0,28 \\
\hline - $\quad$ Tingkat kepatuhan tinggi (skor 8) & $4,72 \pm 1,83$ & & $3,04 \pm 1,60$ & & $2,42 \pm 1,62$ & \\
\hline
\end{tabular}

Tabel IV. Hubungan Usia dengan Penurunan Total Symptom Score

\begin{tabular}{llll}
\hline \multirow{2}{*}{ Variabel } & \multicolumn{2}{l}{ Pengukuran dengan } & Total Symptom Score \\
\cline { 2 - 3 } & delta TSS 1-2 & delta TSS 1-3 & delta TSS 2-3 \\
\hline Usia & 0,39 & 0,75 & 0,81 \\
\hline
\end{tabular}

Tabel V. Hubungan Pemberian Vitamin dan Total Symptoms Score

\begin{tabular}{ccccccc}
\hline & \multicolumn{5}{c}{ Pengukuran dengan Total Symptom Score } \\
\cline { 2 - 7 } Variabel & $\begin{array}{c}\text { TSS } \\
\text { (kunjungan-1) }\end{array}$ & $\begin{array}{c}\text { p-value } \\
\text { (kunjungan 2- } \\
\text { kunjungan 1) }\end{array}$ & $\begin{array}{c}\text { TSS } \\
\text { (kunjungan-2) }\end{array}$ & $\begin{array}{c}p \text {-value } \\
\text { (kunjungan 3- } \\
\text { kunjungan 2) }\end{array}$ & $\begin{array}{c}\text { TSS } \\
\text { (kunjungan-3) }\end{array}$ & $\begin{array}{c}\text { (kunjungan 3- } \\
\text { kunjungan 1) }\end{array}$ \\
\hline $\begin{array}{c}\text { Pemberian } \\
\text { Vitamin B Forte }\end{array}$ & $4,70 \pm 1,83$ & $0,00^{*}$ & $2,99 \pm 1,61$ & $0,00^{*}$ & $2,37 \pm 1,62$ & $0,00^{*}$ \\
\hline
\end{tabular}

Total pasien pada penelitian ini adalah sebanyak 43 pasien dengan pasien perempuan $(53,5 \%)$ dan laki-laki $(46,5 \%)$, pemilihan subjek penelitian dilakukan dengan metode consecutive sampling dimana pasien yang memiliki riwayat diabetes mellitus sebelumnya, dan kemudian dilakukan skrining pemeriksaan neuropati. Penelitian sebelumnya oleh Katulanda (2012), 
bahwa prevalensi jenis kelamin yang menderita neuropati diabetes pada negara berkembang banyak lebih banyak pada wanita. Nampak terlihat adanya perbedaan rata-rata nilai mean TSS pada jenis kelamin laki-laki dan perempuan. Pada nilai mean TSS perempuan didapatkan secara berturut-turut hasilnya lebih tinggi daripada nilai rerata TSS lakilaki, walaupun secara statistik jenis kelamin tidak berpengaruh pada nilai TSS. Sesuai dengan penelitian Fillingim (2009), bahwa secara epidemiologi ditemukan bahwa sensitivitas sensasi nyeri, terjadi lebih banyak pada wanita daripada pria. Penyebab dari hal tersebut bisa dikarenakan oleh banyak faktor antara lain secara biopsychosocial, hormon, dan pain coping (Bartley, 2013).

Rata-rata durasi DM (tahun) pasien adalah $4,47 \pm 4,96$, pada uji bivariat tidak ditemukan nilai yang bermakna antara durasi DM dengan nilai TSS (kunjungan $1 p=0,97$; kunjungan $2 p=0,99$; kunjungan $3 p=0,53)$. Hasil ini berbeda dengan penelitian sebelumnya oleh Davies (2006), didapatkan nilai $p=0,019$ pada durasi DM dan derajat neuropati, yang berarti pasien yang memiliki durasi DM lebih lama secara statistik bermakna pada derajat neuropati; durasi diabetes yang

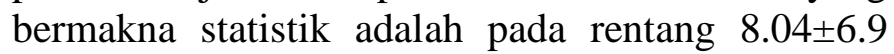
tahun.

Usia rerata pada penelitian ini adalah $56,35 \pm 5,82$ tahun. Analisa statistik usia pada kunjungan-1 $p=0,12$; kunjungan-2 $p=0,04$; kunjungan-3 $p=0,05$ setelah 2 minggu pemberian kombinasi vitamin $B$ forte ternyata nampak bermakna pada kunjungan-2, yaitu $p=0,04$. Uji statistik berkelanjutan dengan regresi logistik didapatkan hasil nilai TSS pada kunjungan 2 $(p=0,02)$ dan kunjungan $3(p=0,03)$ menunjukkan hasil yang bermakna yang berarti diprediksi bahwa kenaikan pada usia akan diimbangi dengan penurunan nilai TSS. Penelitian oleh Perhimpunan Dokter Spesialis Saraf Indonesia (PERDOSSI) tahun 2012 dilakukan pada 5.000 pasien di rumah sakit Jakarta, Surabaya dan Medan pasien yang terskrining neuropati, $81 \%$ kasus menyerang usia 40 tahun ke atas. Studi menurut Lautenbacher (2005), mengindikasi bahwa usia tua memiliki sensitivitas nyeri lebih tinggi daripada usia muda, penelitian juga menyebutkan persepsi nyeri atau rasa tidak nyaman menunjukkan hasil yang kurang konsisten dalam kelompok usia (Wandner, 2011)

Pada penelitian ini dari 43 pasien terdapat 3 pasien yang merokok. Hasil didapatkan bahwa pasien yang tidak merokok memiliki nilai yang bermakna hanya pada penilaian TSS kunjungan-1 $p=0,02$ (kunjungan-2 $p=0,08$; kunjungan-3 $p=$ $0,25)$ dengan nilai mean merokok $4,88 \pm 1,75$ tidak merokok 2,33 $\pm 1,19$, yang diartikan sebagai pasien yang merokok memiliki nilai TSS yang lebih baik dibandingkan dengan yang tidak merokok sebelum diberikan terapi. Merokok merupakan salah satu faktor risiko penyebab munculnya neuropati diabetes yang dapat dimodifikasi (Tesfaye, 2005). Menurut Centre for Disease Control and Prevention (CDC) pada pasien dengan diabetes yang merokok akan meningkatkan kerusakan saraf sehingga menimbulkan komplikasi neuropati perifer dengan gejala mati rasa, nyeri, kurang koordinasi dan kelemahan pada tangan dan kaki. Hasil yang tidak sesuai dapat terjadi dikarenakan jumlah proporsi yang tidak imbang antara pasien yang tidak merokok 40 pasien dan merokok 3 pasien.

Menurut penelitian kejadian neuropati diabetes terjadi karena multifaktorial yang berhubungan dengan gangguan metabolik, stress oxidative, dan defisiensi growth factor (Tesfaye, 2011). Pada penelitian Pasien yang memiliki dislipidemi berjumlah 11 pasien dari 43 orang. Didapatkan hasil yang bermakna pada kunjungan$2 P=0,04$ dengan dengan nilai mean pasien yang tanpa dislipidemia $3,27 \pm 1,58$, yang mengalami dislipidemia 2,18 $\pm 1,47$, diartikan bahwa setelah 2 minggu terapi dan dilakukan penilaian TSS, hasil menunjukkan pasien yang memiliki dislipidemia memiliki nilai TSS yang lebih baik atau mengalami penurunan TSS yang lebih baik daripada pasien tanpa dislipidemia. Hal ini tidak sesuai bahwa tingginya kadar gula darah dengan tingginya kadar lemak dalam darah yang membawa terjadi stress oxidative hingga terjadinya kerusakan pada saraf (Vincent, 2011). Penelitian yang pernah dilakukan sebelumnya oleh 
Wiggin et al. (2009) bahwa tingginya trigliserida merupakan satu-satunya parameter klinis yang berkolerasi terhadap hilangnya densitas serabut saraf pada pasien neuropati diabetes. Hal tersebut dikarenakan pasien diberikan terapi untuk mengontrol kadar lemak darah dan pemberian terapi kombinasi vitamin yang sudah dilakukan selama 2 minggu membantu didalam penurunan nilai total gejala. Nilai mean tampak turun pada kunjungan ke 3 namun secara statistik tidak signifikan.

Pasien hipertensi pada penelitian ini berjumlah 17 orang. Pada hasil tidak tampak adanya kebermaknaan nilai secara statistik antara hipertensi dan penurunan nilai TSS setelah pemberian kombinasi vitamin $\mathrm{B}$ forte (kunjungan $1 p=0,49$; kunjungan $2 p=0,98$; kunjungan $3 p=0,73$ ) hanya jika dilihat pada nilai mean terlihat penurunan nilai TSS dari kunjungan 1 sampai dengan kunjungan 3. Secara teori hipertensi dan tingginya kadar gula dalam darah dapat mempercepat komplikasi mikrovaskular dan makrovaskular yang dapat menyebabkan kerusakan serabut saraf dan menimbulkan gejala neuropati (Schutta, 2007). Hasil tidak bermakna juga dijumpai pada pasien dengan ulkus diabetes dikarenakan persebaran pasien dengan ulkus tidak sebanding yaitu hanya 1 pasien dari 43 pasien.

Terjadinya neuropati diabetes pada teori vaskular disebutkan bahwa kandungan darah yang cenderung hiperglikemi menyebabkan terjadinya resistensi pembuluh darah yang membuat pasokan darah menuju endoneurium menjadi terhambat yang dapat menyebabkan kerusakan pada saraf (Sjahrir, 2006). Terapi diabetes melitus untuk mengontrol tingginya gula darah menurut guideline American Diabetes Association (ADA) adalah dengan obat hiperglikemik oral (OHO) dan penggunaa insulin. Pengobatan dapat dilakukan secara monoterapi maupun kombinasi sesuai dengan kondisi pasien. Anjuran oleh American Diabetes Association ADA pengobatan monoterapi yang dapat diberikan dengan tingkat efisinsi tinggi adalah methformin. Pada penelitian ini jumlah pasien yang menggunakan OHO sebanyak $42(97,7 \%)$ pasien dan yang menggunakan insulin sebanyak $4(9,3 \%)$. Pada penelitian ini peneliti tidak memeriksa kadar gula darah pasien, peneliti hanya mengamati terapi diabetes yang digunakan pasien dalam mengontrol kadar gula darah. Penggunaan terapi OHO maupun terapi insulin tidak terbukti secara statistik mempengaruhi penurunan nilai TSS pada penelitian ini. Menurut National Institute of Diabetes and Digestive and Kidney Diseases (NIDDK) (2013) cara terbaik mencegah dan memperbaiki neuropati salah satunya dengan mengontrol kadar gula dalam darah dalam batas normal. Menjaga kadar gula dalam batas normal membantu menjaga serabut saraf

Penelitian oleh Reinstatler (2012), menemukan adanya hubungan penggunaan obat hiperglikemik oral khususnya methformin dengan defisiensi vitamin $\mathrm{B}_{12}$. Defisiensi $\mathrm{B}_{12}$ ditemukan pada $5,8 \%$ pasien diabetes dengan methformin dan $2,4 \%$ pada pasien diabetes tanpa terapi methformin dengan nilai $P=0,0026$. Defiseinsi vitamin $\mathrm{B}_{12}$ dari penggunaan methformin juga dapat menimbulkan munculnya neuropati perifer (David, 2010).

Pada penelitian ini seluruh sampel diberikan terapi kombinasi vitamin $\mathrm{B}_{1}, \mathrm{~B}_{6}$, dan $\mathrm{B}_{12}$ dosis forte yaitu $B_{1}: 100 \mathrm{mg}, B_{6}: 100 \mathrm{mg}, B_{12}: 5000 \mathrm{mcg}$ diminum 1 kali sehari. Pemberian terapi dilakukan selama 1 bulan dengan penilaian pengukuran sebanyak 3 kali pada hari ke-0, hari ke-14 dan hari ke-30. Penelitian secara umum tidak terdapat efek samping yang cukup serius dalam penggunaan vitamin ini. Tiga dari 43 sampel yang ada memiliki reaksi terhadap terapi vitamin B antara lain mual, muntah dan diare. pemberian kombinasi vitamin khususnya vitamin $\mathrm{B}_{1}, \mathrm{~B}_{6}$, dan $\mathrm{B}_{12}$. Fungsi vitamin $\mathrm{B}_{12}$ berperan dalam metabolisme asam lemak yang berguna dalam memperbaiki serabut myelin saraf. Peran vitamin $\mathrm{B}_{1}$ adalah menginisiasi impuls saraf dari koenzim dan $\mathrm{B}_{6}$ terlibat dalam sintesis neurotransmitter sehingga membuat keduanya berfungsi dalam memperbaiki neuropati (Pazirandeh, 2009).

Pengukuran dilakukan menggunakan penilaian total symptoms score dengan penilainan gejala antara lain nyeri, rasa terbakar, kesemutan dan mati rasa. Terdapat penurunan penilaian TSS dengan nilai mean pada masing-masing 
kunjungan-1 (4,70 $\pm 1,83)$, kunjungan-2 $(2,99 \pm 1,61)$ dan kunjungan-3 $(2,37 \pm 1,62)$ dengan total minimum 0,00 dan maksimum 9,66. Hasil analisa bivariat berdasarkan hasil uji statistik terdapat perbedaan antara total symptoms score (TSS) pada kunjungan 2 dengan kunjungan 1 dengan nilai $p=$ 0,00 , dilihat dari rerata mean TSS kunjungan 1 ke kunjungan 2 menunjukkan penurunan. Perbedaan juga didapati pada nilai TSS kunjungan 3 dan kunjungan 1 serta kunjungan 3 dan kunjungan 2 yang kemudian diuji secara statistik bermakna dengan nilai masing $p=0,00$. Penurunan mean pada TSS kunjungan 1 ke kunjungan 3 dan kunjungan 2 ke kunjungan 3 juga terdapat penurunan. Hal ini terbukti bahwa terdapat penurunan TSS setelah pemberian terapi kombinasi vitamin B1, B6 dan B12.

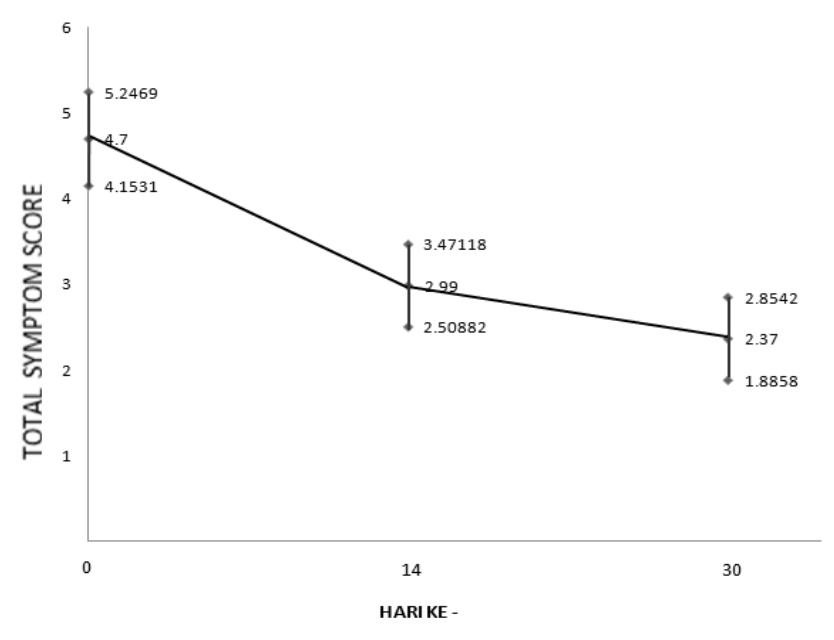

Gambar 1. Grafik Pemberian Vitamin Kombinasi $\mathrm{B}_{1}, \mathrm{~B}_{6}$ dan $\mathrm{B}_{12}$ Forte dengan Total Symptoms Score (CI: 95\%)

Sesuai dengan penelitian Farvid (2011), yaitu pemberian suplementasi $B_{1}(10 \mathrm{mg}), B_{2}(10 \mathrm{mg}), B_{6}$ $(10 \mathrm{mg})$, biotin $(200 \mathrm{mg}), \mathrm{B}_{12}(10 \mathrm{mg})$ dan asam folat $(1 \mathrm{mg})$ dengan penilaian dengan Michigan Neuropathy Screening Instrument (MNSI) didapatkan penurunan dari 3,96 menjadi 1,00 nilai $p$ $=0,01$. Penelitian yang bermakna juga ditemukan oleh Rizvi (2013), kombinasi vitamin $\mathrm{B}_{1}$ (100mg), $\mathrm{B}_{6}(100 \mathrm{mg})$, dan $\mathrm{B}_{12}(200 \mathrm{mcg})$ efektif pada 177 $(57 \%)$ pasien dari 310 pasien dengan neuropati diabetes. Penelitian ini juga diukur tingkat kepatuhan pasien meminum obat menggunakan tes morisky. Pasien terbagi menjadi tingkat kepatuhan rendah $0(0 \%)$ pasien, tingkat kepatuhan rendah 1 $(2,3 \%)$ pasien, dan tingkat kepatuhan tinggi 42 $(97,7 \%)$. Tidak ditemukan hubungan antara tingkat kepatuhan dengan penurunan total symptoms score, dikarenakan tingkat kepatuhan yang tinggi hampir merata pada seluruh pasien.

\section{KESIMPULAN}

Pemberian kombinasi vitamin $\mathrm{B}_{1}, \mathrm{~B}_{6}$ dan $\mathrm{B}_{12}$ menunjukkan adanya kecenderungan sebagai faktor determinan penurunan nilai total gejala (nyeri, rasa terbakar, kesemutan dan mati rasa) pada pasien neuropati perifer diabetes.

\section{DAFTAR PUSTAKA}

Bartley, E. J., Fillingim R. B., 2013. Sex Differences in Pain: A Brief Review of Clinical and Experimental Findings. Ed. L. Colvin and D. J. Rowbotham. BJA: British Journal of Anaesthesia, 111.1, 52-58.

David, S.H., Bell, M.D., 2010. Metformin-Induced Vitamin B12 Deficiency Presenting as a Peripheral Neuropathy. South Med J., 103(3), 265-267.

Davies, M., Brophy, S., Williams R., Taylor., 2006. The Prevalence, Severity, and Impact Painful Diabetic Peripheral Neuropathy in Type 2 Diabetes. Diabetes Care Vol, 29 (7), 1518-1522.

Farvid, M.S., Homayouni, F., Amiri, Z., Adelmanesh, F., 2011. Improving neuropathy scores in type 2 diabetic patients using micronutrients supplementation. Diabetes research and clinical practice, 93(20II), 8694.

Fillingim, R.B., King, C.D., Ribeiro-Dasilva, MC., Rahim-Williams, B., Riley J.L. III., 2009. Sex, gender, and pain: a review of recent clinical and experimental findings. J Pain 10, 447-85.

International Diabetes Federation, 2013. IDF Diabetes Atlas $6^{\text {th }}$ Edition. (Online), 
http://idf.org/diabetesatlas/ accessed 28 October 2015.

Katulanda, P., Ranasinghe, P., Jayawardena, R., Constantine, G.R., Sheriff, M.H.R., Matthews, D.R., 2012. The prevalence, patterns and predictors of diabetic peripheral neuropathy in a developing country. Diabetology \& Metabolic Syndrome, 4, 21.

Lautenbacher, S., Kunz, M., Strate, P., Nielsen, J., Arendt-Nielsen, L., 2005. Age effects onpain thresholds, temporal summation and spatial summation of heat and pressure. The Journal of Pain, 115(3), 410-8.

National Institute of Diabetes and Digestive and Kidney Disease (NIDDK), 2013. Nerve Damage (Diabetic Neuropathies) (Online), https://www.niddk.nih.gov/health-

information/diabetes/preventing-diabetesproblems/nerve-damage-diabetic-neuropathies accessed 5 November 2015.

Pazirandeh, S., Burns, D.L., 2009. Overview of water soluble vitamins. (Online), http://www.uptodate.com/contents/ accessed 18 November 2015.

Perhimpunan Dokter Spesialis Saraf Indonesia (PERDOSSI) dan MERCK Indonesia, 2012. Siaran Pers: Neuropati Perifer Diabetes. (Online),

http://www.merck.co.id/country.id/id/images/Si aran\%20Pers\%20N5000\%20Makassar 4Oct tc $\underline{\text { m663_104054.pdf?Version=l accessed } 16}$ Maret 2016.

Reinstatler, L., Qi, Y.P., Williamson, R.S., Garn, J.V., Oakley, G.P., 2012. Association of Biochemical $B_{12}$ Deficiency with Metformin Therapy and Vitamin $\mathrm{B}_{12}$ Supplements. Diabetes Care, 35(2): 327-333.

Rizvi, A., A. Ahmad, Z., Rizvi, 2013. Efficacy of combination of vitamin B1, B6 and B12 in management of diabetic peripheral neuropathy (Online),
http://pjmhsonline.com/JulySept2013/efficacy _of_combination_of_vitamin_B1B6,b12.htm/ accessed 30 October 2015.

Schutta, M. H., 2007. Diabetes and hypertension: epidemiology of the relationship and pathophysiology of factors associated with these comorbid conditions. $J$ Cardiometab Syndr, 2(2), 124-30.

Sjahrir, H., 2006. Diabetic Neuropathy: The Patoneubiology \& Treatment Update. Medan: USU Press.

Sudoyo, A. W., Setiyohadi, B., Alwi, I., Simadibrata, M., Setiati, S., 2009. Buku Ajar Ilmu Penyakit Dalam,Jilid III Edisi V. Jakarta: Interna Publishing.

Tesfaye, S., Chaturvedi, N., Eaton, S., et al., 2005. Vascular risk factors and diabetic neuropathy. N Engl J Med, 352, 341-50.

Tesfaye, S., Vileikyte, L., Rayman, G., et al., 2011. Painful Diabetic Peripheral Neuropathy: consensus recommendation on diagnosis, assessment and management. Diabetes Metabolism Research and Reviews 27(1), 62938.

Vincent, A. M., Hinder, L. M., Pop-Busui, R., Feldman, E. L., 2011. Hyperlipidemia: A New Therapeutic Target for Diabetic Neuropathy. JPNS, 14(4), 257-267.

Wandner, L. D., Scipio, C. D., Hirsh, A. T., Torres, C. A., \& Robinson, M. E., 2011. The Perception of Pain in Others: How Gender, Race and Age Influence Pain Expectation. The Journal of Pain, 13(3), 220-227.

Wiggin, T.D., Sullivan, K.A., Pop-Busui, R., Amato, A., Sima, A.A., Feldman, E.L., 2009. Elevated Triglycerides Correlate With Progression of Diabetic Neuropathy. Diabetes, 58(7), 1634-1640. 